\title{
PENGARUH KEPUASAN KERJA TERHADAP PROXIMAL WITHDRAWAL STATES PADA KARYAWAN PERUSAHAAN PERBANKAN
}

\author{
Venesia $^{1}$, Tumanggor, R. O. Tumanggor ${ }^{2}$ dan P. Tommy Y. S. Suyasa ${ }^{3}$ \\ ${ }^{1}$ Program Studi Psikologi Profesi Jenjang Magister, Universitas Tarumanagara, Jakarta \\ Email: venesia31@gmail.com \\ ${ }^{2}$ Fakultas Psikologi, Universitas Tarumanagara, Jakarta \\ Email: rajat@fpsi.untar.ac.id \\ ${ }^{3}$ Fakultas Psikologi, Universitas Tarumanagara, Jakarta \\ Email: tommys@fpsi.untar.ac.id
}

Masuk : 15-04-2019, revisi: 26-04-2020, diterima untuk diterbitkan : 26-04-2020

\begin{abstract}
Banks play an important role in a country's economy. However, banks face various challenges in meeting their objectives. One of the challenges faced by some banks is a high employee turnover rate. In regards to turnover, there is a new concept of proximal withdrawal states proposed by Hom, Mitchell, Lee, and Griffeth (2012) as the closest and more accurate predictor of turnover than intention to leave (Li, Lee, Mitchell, Hom, \& Griffeth, 2016).Proximal withdrawal states is the condition of one's motivation towards the company where he/she works, which consists of two dimensions, namely (a) preference to leave or stay in the company (intention to leave) and (b) control of those desires (perceived control over preference). The combination of the two dimensions forms four types of proximal withdrawal states, namely enthusiastic leavers, reluctant stayers, reluctant leavers, and enthusiastic stayers. Job satisfaction, which has a significant negative relationship with intention to quit (Masum et al., 2016), proved to be more accurate in predicting turnover when analyzed with proximal withdrawal states (Li et al., 2016).This study aims to determine the effect of job satisfaction on proximal withdrawal states in banking company employees. This study uses descriptive non-experimental research method, with purposive sampling technique. 273 banking company employees who participated in this study. The results of the analysis using multinominal logistic regression testing showed the effect of job satisfaction on proximal withdrawal states for banking employees. The higher the level of job satisfaction of banking employees, the greater the tendency for employees to become enthusiastic stayers or reluctant stayers, both of whom have a desire to remain in the company.
\end{abstract}

Keywords: job satisfaction, proximal withdrawal states, turnover, banking

\begin{abstract}
ABSTRAK
Bank memiliki peran penting bagi perekonomian negara. Namun bank menghadapi berbagai tantangan dalam memenuhi tujuannya. Salah satu tantangan yang dihadapi beberapa bank adalah tingkat turnover karyawan yang tinggi. Terkait dengan turnover, terdapat konsep baru mengenai proximal withdrawal states yang diusulkan oleh Hom, Mitchell, Lee, dan Griffeth (2012) sebagai faktor (prediktor) yang paling dekat dan lebih akurat untuk memprediksi turnover dibandingkan intention to leave (Li, Lee, Mitchell, Hom, \& Griffeth, 2016). Proximal withdrawal states adalah kondisi motivasi seseorang terhadap perusahaan di mana ia bekerja, yang terdiri dari dua dimensi yaitu (a) preferensi untuk keluar atau menetap di perusahaan (intention to leave) dan (b) kendali atas keinginan tersebut (perceived control over preference). Perpaduan kedua dimensi tersebut membentuk empat jenis proximal withdrawal states, yaitu enthusiastic leavers, reluctant stayers, reluctant leavers, dan enthusiastic stayers. Kepuasan kerja, yang memiliki hubungan signifikan negatif dengan intention to quit (Masum et al., 2016), terbukti semakin akurat dalam memprediksi turnover ketika dianalisis dengan proximal withdrawal states (Li et al., 2016). Penelitian ini bertujuan mengetahui pengaruh kepuasan kerja terhadap proximal withdrawal states pada karyawan perusahaan perbankan. Penelitian ini menggunakan metode penelitian non eksperimental deskriptif, dengan teknik purposive sampling. Terdapat 273 karyawan perusahaan perbankan yang menjadi partisipan dalam penelitian ini. Hasil analisis dengan pengujian regresi logistik multinominal menunjukkan adanya pengaruh kepuasan kerja terhadap proximal withdrawal states pada karyawan perbankan. Semakin tinggi tingkat kepuasan kerja karyawan perbankan, maka semakin besar peluang karyawan untuk menjadi enthusiastic stayers ataupun reluctant stayers, di mana keduanya memiliki keinginan untuk menetap di perusahaan.
\end{abstract}

Kata Kunci: kepuasan kerja, proximal withdrawal states, turnover, perbankan 


\section{PENDAHULUAN}

Bank memiliki peran yang penting bagi perekonomian negara. Namun demikian, perusahaan perbankan tidak terlepas dari tantangan. Hasil survei gaji 2015 yang diadakan oleh Mercer Talent Consulting and Information Solution, menunjukkan bahwa tingkat turnover perusahaan perbankan tergolong paling tinggi dibandingkan dengan industri lainnya di Indonesia (Prahadi, 2015), yaitu antara 7.3\% (berdasarkan hasil studi pada ajang Indonesia Human Capital Studi; dalam Romualdus, 2016) sampai dengan 10\% (PwC, 2014). Bahkan, beberapa bank swasta memiliki tingkat turnover lebih dari 10\%, yaitu sekitar 12\% - 15\% (Djaja, Mardanugraha \& Sihombing, 2015).

Terdapat berbagai alasan yang memicu keinginan karyawan untuk keluar dari perusahaan. Hasil survei PwC (2014) menunjukkan bahwa alasan karyawan perusahaan perbankan mengundurkan diri adalah untuk mendapatkan tunjangan yang lebih baik, kesempatan pengembangan karir, mendapatkan tugas yang lebih menantang, serta merasa tidak puas dengan atasan. Keinginan untuk keluar dari perusahaan ini dikenal sebagai intention to leave.

Berbagai penelitian telah dilakukan untuk mengkaji faktor intention to leave dalam kaitannya dengan turnover. Meskipun intention to leave merupakan faktor yang paling dekat dengan turnover dan paling kuat dalam memprediksi turnover, namun variance turnover pada intention to leave tidak lebih dari 30\% (sebesar 4\% sampai dengan 8\%, Griffeth, Hom, \& Gaertner, 2000; sebesar 8.9\%, Li et al., 2016; sekitar 27\%, Tett \& Meyer, 1993). Ketika seseorang memiliki keinginan untuk keluar, belum tentu ia akan melakukan tindakan untuk keluar dari perusahaan (Allen, Weeks, \& Moffitt, 2005; Mai, Ellis, Christian, \& Porter,2016).

Oleh karena itu, Hom et al. (2012) mengusulkan bahwa intention to leave bukanlah faktor yang paling dekat dengan turnover. Dalam memprediksi seseorang akan menetap atau keluar dari perusahaan, tidak cukup hanya berdasarkan motivasi atau preferensinya saja (intention to leave). Melainkan juga perlu mengetahui kendali yang dirasakan seseorang terhadap preferensinya tersebut. Kendali yang dirasakan seseorang atas preferensinya untuk menetap atau keluar dari perusahaan ini disebut juga sebagai perceived control over preference.

Perpaduan kedua faktor tersebut merupakan faktor yang paling dekat dengan turnover dan lebih akurat dalam memprediksi turnover dibandingkan hanya menggunakan faktor intention to leave saja. Dengan kata lain, ketika intensi seseorang didukung dengan adanya kendali yang dimiliki atas intensi tersebut, maka ia akan lebih mungkin untuk bertindak sesuai dengan intensinya tersebut. Perpaduan kedua faktor tersebut membentuk kondisi motivasi seseorang terkait dengan perusahaan di mana ia bekerja, yang disebut sebagai proximal withdrawal states. Proximal withdrawal states terdiri dari empat jenis kondisi, yaitu enthusiastic leavers, reluctant stayers, reluctant leavers, serta enthusiastic stayers.

Enthusiastic leavers adalah kondisi motivasi seseorang dengan keinginan atau intensi keluar dari perusahaan dan ia merasa memiliki kendali atas keinginannya untuk keluar dari perusahaan. Dengan demikian, enthusiastic leavers cenderung untuk melakukan tindakan keluar dari perusahaan karena ia memiliki intensi tersebut dan kendali untuk merealisasikannya ada pada orang tersebut. Sebaliknya, reluctant stayers adalah kondisi motivasi seseorang dengan keinginan untuk keluar dari perusahaan namun ia merasa tidak memiliki kendali atas keinginannya untuk keluar. Oleh karena itu, reluctant stayers cenderung menetap di perusahaan namun dengan rasa terpaksa karena ia merasa tidak mampu untuk merealisasikannya. 
Enthusiastic stayers merupakan kondisi motivasi seseorang dengan keinginan untuk menetap di perusahaan dan ia merasa memiliki kendali atas keinginannya tersebut. Ia pun cenderung melakukan tindakan menetap di perusahaan karena ia memiliki keinginan untuk menetap dan ia memiliki kendali untuk tetap bekerja di perusahaan. Namun halnya dengan reluctant leavers, yang merupakan kondisi motivasi seseorang dengan keinginan untuk menetap di perusahaan namun ia merasa tidak memiliki kendali atas keinginannya tersebut. Sehingga, ia pun dengan berat hati harus keluar dari perusahaan karena faktor eksternal mendesak atau membuat ia harus keluar dari perusahaan.

Proximal withdrawal states terbukti lebih akurat untuk memprediksi turnover (Li et al., 2016). Tingkat turnover pada kelompok karyawan dengan preferensi menetap di perusahaan dan memiliki kendali atas preferensinya tersebut (enthusiastic stayers) paling rendah dibandingkan dengan ketiga kelompok lainnya (reluctant stayers, reluctant leavers, dan enthusiastic leavers). Demikian juga, kelompok karyawan yang ingin keluar dan merasa memiliki kendali atas keinginannya tersebut (enthusiastic leavers) memiliki tingkat turnover dibandingkan dengan ketiga kelompok lainnya. Melalui penelitiannya, Li et al. (2016) pun membuktikan adanya perbedaan proximal withdrawal states ditinjau dari kepuasan kerja. Karyawan dengan preferensi menetap di perusahaan dan memiliki kendali atas preferensinya tersebut (enthusiastic stayers), memiliki tingkat kepuasan kerja lebih tinggi dibandingkan dengan karyawan yang ingin keluar dari perusahaan namun tidak memiliki kendali atas keinginannya tersebut (reluctant stayers) maupun dengan karyawan yang ingin keluar dan memiliki kendali atas keinginannya tersebut (enthusiastic leavers).

Dalam kaitannya dengan turnover, kepuasan kerja merupakan salah satu faktor yang mempengaruhi keinginan seseorang untuk menetap atau keluar dari perusahaan. Semakin rendah tingkat kepuasan kerja seseorang, maka semakin tinggi keinginan seseorang untuk keluar dari perusahaan (Ramalho Luz, Luiz de Paula, \& de Oliveira, 2018). Demikian juga dengan ketidakpuasan kerja (job dissatisfaction). Seseorang dengan ketidakpuasan kerja cenderung memutuskan untuk keluar dari perusahaan (Griffeth et al., 2000; Masum et al., 2016).

Namun demikian, kepuasan kerja pun belum cukup akurat dalam memprediksi turnover. Ketika seseorang memiliki tingkat kepuasan kerja yang rendah, belum tentu mereka akan langsung melakukan tindakan keluar dari perusahaan (Maertz \& Campion, 2004). Penelitian Luther, Gearhart, Fukui, Morse, Rollins dan Salyers (2017) pada dokter di bidang kesehatan mental di Indiana dan Missouri menunjukkan bahwa tidak terdapat perbedaan tingkat keinginan untuk keluar dari perusahaan (intention to leave) antara dua kelompok yang berbeda tingkat kepuasan kerjanya secara signifikan.

Kepuasan kerja menjadi lebih akurat dalam memprediksi turnover ketika dianalisis dengan proximal withdrawal states (Li et al., 2016). Pada kelompok karyawan yang merasa memiliki kendali atas preferensinya (enthusiastic stayers dan enthusiastic leavers), semakin tinggi tingkat kepuasan kerja maka semakin rendah tingkat job search behavior dan intention to leave. Dengan kata lain, karyawan yang merasa memiliki kendali atas preferensinya (enthusiastic stayers dan enthusiastic leavers) cenderung melakukan tindakan menetap atau keluar dari perusahaan berdasarkan kepuasan kerjanya. Sedangkan karyawan yang merasa kurang memiliki kendali atas preferensinya, cenderung melakukan tindakan menetap atau keluar dari perusahaan berdasarkan kendali dari faktor eksternal misalnya mengikuti suami pindah ke luar kota, atasan memutuskan 
untuk tidak melanjutkan kontrak kerja karyawan, adanya pengurangan karyawan dari perusahaan.

Sudah terjelaskan bahwa proximal withdrawal states lebih akurat dalam memprediksi turnover dibandingkan intention to leave. Sudah terjelaskan juga bahwa kepuasan kerja lebih akurat dalam memprediksi turnover jika dianalisis dengan proximal withdrawal states. Namun demikian, kajian mengenai proximal withdrawal states masih sangat sedikit ditemukan, dan belum terdapat penelitian mengenai proximal withdrawal states pada karyawan perbankan. Tujuan penelitian ini untuk mengetahui pengaruh kepuasan kerja terhadap proximal withdrawal states pada karyawan perusahaan perbankan. Penelitian ini untuk menambahkan kajian mengenai proximal withdrawal states. Pemahaman ini pun akan berguna bagi perusahaan, khususnya perusahaan perbankan dalam menyusun strategi yang tepat untuk mengurangi turnover dengan menerapkan strategi yang berbeda berdasarkan jenis proximal withdrawal states.

Rumusan masalah dalam penelitian ini berdasarkan latar belakang dan fenomena penelitian adalah bagaimana pengaruh kepuasan kerja terhadap proximal withdrawal states pada karyawan perusahaan perbankan.

\section{METODE PENELITIAN}

Partisipan dalam penelitian ini adalah karyawan yang bekerja di perusahaan perbankan yang berstatus kepegawaian sebagai karyawan tetap ataupun kontrak, dengan masa kerja minimal enam bulan dan berlokasi kerja di Indonesia. Jumlah awal partisipan yang mengisi kuesioner dalam penelitian ini adalah 432 partisipan. Setelah dilakukan screening pada biodata partisipan, tersisa 407 partisipan. Setelah dilakukan validasi alat ukur proximal withdrawal states, jumlah partisipan yang tersisa dan digunakan datanya sebagai partisipan dalam penelitian ini adalah sebanyak 273 orang. Partisipan terdiri dari 31 partisipan enthusiastic leavers, 98 partisipan reluctant stayers, 47 partisipan reluctant leavers, dan 97 partisipan enthusiastic stayers. Rentang usia partisipan antara usia 19 tahun sampai 56 tahun.

\section{Proximal withdrawal states}

Proximal withdrawal states diukur dengan alat ukur yang dikembangkan oleh Li et al. (2016). Alat ukur ini terdiri dari satu butir pertanyaan mengenai situasi di perusahaan yang ia sedang alami dan partisipan diminta memilih satu dari empat situasi yang paling menggambarkan perasaannya mengenai perusahaannya saat ini. Keempat situasi tersebut merupakan uraian dari empat jenis proximal withdrawal states yaitu (a) situasi 1 mencerminkan enthusiastic leavers berupa "Situasi 1: Saya ingin keluar dari perusahaan ini; dan saya merasa bisa merealisasikannya kapan saja", (b) situasi 2 mencerminkan reluctant stayers berupa "Situasi 2: Saya ingin keluar dari perusahaan ini; namun saya merasa belum bisa merealisasikannya (belum waktunya)", (3) situasi 3 menggambarkan reluctant leavers berupa "Situasi 3: Saya sebenarnya ingin tetap bertahan di perusahaan ini; namun kondisi saya membuat saya harus keluar", dan (4) situasi 4 merupakan enthusiastic stayers berupa "Situasi 4: Saya ingin bertahan di perusahaan ini; sampai kapanpun saya mau".

\section{Validasi Proximal withdrawal states}

Setelah partisipan memilih satu jawaban pada alat ukur proximal withdrawal states, kuesioner akan dilanjutkan dengan alat ukur untuk validasi proximal withdrawal states, yang terdiri dari (1) butir-butir tambahan proximal withdrawal states, (2) alat ukur intention to leave, dan (3) alat ukur perceived control over staying dan perceived control over leaving. Validasi ini dilakukan mempertimbangkan proximal withdrawal states hanya diukur dengan menggunakan satu butir pertanyaan saja yang diisi dengan metode self-identified. 
Pertama, validasi dilakukan dengan memeriksa konsistensi jawaban partisipan dari alat ukur proximal withdrawal states dengan butir-butir pernyataan berisi rincian dari setiap jenis proximal withdrawal states. Butir pada tahap ini dijawab dengan menggunakan skala 1 (tidak setuju) sampai dengan 4 (setuju). Partisipan dengan nilai rata-rata di atas 2.5 pada bagian ini, dianggap konsisten dengan jenis proximal withdrawal states yang telah ia pilih. Butir-butir yang akan dihadapi oleh setiap partisipan akan berbeda-beda berdasarkan pada jawaban situasi yang dipilih partisipan pada alat ukur proximal withdrawal states.

Ketika partisipan memilih situasi satu (enthusiastic leavers), maka ia akan dihadapkan pada empat butir tambahan mengenai enthusiastic leavers (nilai reliabilitas $\alpha=0.865$ ). Contoh butirnya adalah "Saya ingin keluar dari perusahaan saya saat ini dan tidak ada yang bisa membuat saya tetap bekerja di perusahaan ini". Jika partisipan memilih situasi dua (reluctant stayers), maka ia akan dihadapkan pada lima butir tambahan mengenai reluctant stayers (nilai reliabilitas $\alpha=0.516$ ). Contoh butirnya adalah "Saya ingin keluar dari perusahaan saya saat ini tetapi hal ini akan sulit untuk dilakukan". Partisipan yang memilih situasi tiga (reluctant leavers) akan dihadapkan pada empat butir tambahan mengenai reluctant leavers (nilai reliabilitas $\alpha=0.612$ ). Contoh butirnya adalah "Jika saya keluar dari perusahaan saya saat ini dalam waktu dekat, maka hal ini akan sangat disebabkan oleh faktor luar yang tidak dapat saya kendalikan, tetapi saya ingin tetap bekerja di perusahaan ini". Partisipan yang memilih situasi empat (enthusiastic stayers) akan dihadapkan pada empat butir tambahan mengenai enthusiastic stayers (nilai reliabilitas $\alpha=0.871$ ). Contoh butirnya adalah "Saya ingin menetap di perusahaan saya saat ini dan saya dapat melakukannya".

Kedua, validasi dilakukan dengan memeriksa konsistensi jawaban partisipan dari alat ukur proximal withdrawal states dengan dimensi preferensi dari alat ukur intention to leave yang dikembangkan oleh Robinson (2014), untuk mengukur preference for leaving. Alat ukur ini dijawab dengan menggunakan skala 1 (tidak setuju) sampai dengan 4 (setuju). Semakin tinggi skor yang diperoleh pada alat ukur ini, maka semakin tinggi intensi untuk keluar dari perusahaan. Alat ukur ini terdiri dari empat butir, dengan nilai reliabilitas $0.892(\alpha=0.892)$. Contoh butirnya adalah "Saya ingin meninggalkan perusahaan saya saat ini".

Ketiga, validasi dilakukan dengan memeriksa konsisten jawaban partisipan dari alat ukur preference for leaving dengan dimensi perceived control over preference dari alat ukur perceived control over staying dan perceived control over leaving, yang mengacu pada teori planned behavior Ajzen (1991; Li et al., 2016). Alat ukur ini dijawab dengan menggunakan skala 1 (tidak setuju) sampai dengan 4 (setuju). Semakin tinggi skor yang diperoleh pada alat ukur ini, maka semakin besar kendali yang dirasakan oleh partisipan atas preferensi yang ia miliki. Alat ukur ini terdiri dari tiga butir pernyataan mengenai perceived control over staying dengan nilai reliabilitas $0.731(\alpha=0.731)$ dan tiga butir pernyataan mengenai perceived control over leaving dengan nilai reliabilitas $0.682(\alpha=0.682)$. Contoh butir perceived control over staying adalah "Keputusan apakah saya dapat bekerja di perusahaan saya saat ini atau tidak, sepenuhnya saya yang menentukan". Contoh butir perceived control over leaving adalah "Keputusan apakah saya dapat keluar dari perusahaan saya saat ini atau tidak, sepenuhnya saya yang menentukan".

\section{Kepuasan kerja}

Variabel kepuasan kerja diukur dengan alat ukur kepuasan kerja yang dikembangkan oleh Brayfield dan Rothe (1951), dengan hanya menggunakan beberapa butir saja dari alat ukur ini (Curry, Wakefield, Price, \& Mueller, 1986). Alat ukur ini dijawab dengan menggunakan skala 1 (tidak setuju) sampai dengan 4 (setuju). Semakin tingg skor yang diperoleh pada alat ukur ini, 
maka semakin tinggi tingkat kepuasan kerja. Alat ukur ini terdiri dari tujuh butir dengan nilai reliabilitas $0.874(\alpha=0.874)$. Contoh butir alat ukur ini adalah "Tugas / pekerjaan saya cukup menyenangkan".

\section{HASIL DAN PEMBAHASAN}

Gambaran mengenai proximal withdrawal states dan kepuasan kerja pada karyawan perbankan didapatkan dengan menggunakan analisis regresi logistik multinomial. Sebagian besar partisipan penelitian $(68.0 \%)$ merasa puas dan menyukai pekerjaannya secara umum $(M=2.88$ dan $S D=$ 0.75). Sebagian besar partisipan tergolong dalam kelompok reluctant stayers (35.9\%). Kelompok terbanyak kedua adalah kelompok enthusiastic stayers (35.5\%), kemudian diikuti oleh kelompok reluctant leavers (17.2\%) dan kelompok enthusiastic leavers (11.4\%).

Hasil pengujian kesesuaian model (model fit) dengan pengujian Pearson menunjukkan bahwa model (kepuasan kerja terhadap proximal withdrawal states sesuai dan prosses pengujian dapat dilanjutkan (nilai Pearson Chi-Square $(\chi 2)=62.416$ dan signifikansi $(p)=0.290>0.05$ ). Selanjutnya, hasil pengujian signifikansi model secara simultan menggunakan likelihood ratio test menunjukkan bahwa kepuasan kerja memiliki pengaruh signifikan terhadap proximal withdrawal states $($ nilai Chi-Square $(\chi 2)=101.490$ dan signifikansi $(\mathrm{p})=0.000<0.05$ ) pada karyawan perusahaan perbankan. Kepuasan kerja mempengaruhi proximal withdrawal states sebesar $31.0 \%$ (nilai Pseudo R2 $=0.310$; kontribusi efektif $=31.0 \%$ ). Terdapat variabel lain yang mempengaruhi proximal withdrawal states sebesar $69.0 \%$ selain kepuasan kerja.

Tabel 1. Analisis Regresi Logistik Multinominal (Estimasi Model)

\begin{tabular}{cccccccc}
\hline Prediktor & \multicolumn{2}{c}{$\begin{array}{c}\text { Perbandingan Antar } \\
\text { Jenis PWS }\end{array}$} & $B$ & Wald & $P$ & $\begin{array}{c}\operatorname{Exp}(B) / \\
\text { OR }\end{array}$ & Hasil \\
\hline Kepuasan & EL & RS & -0.649 & 4.272 & 0.039 & 0.523 & Signifikan* \\
\cline { 3 - 8 } Kerja & & RL & 1.067 & 8.140 & 0.004 & 2.907 & Signifikan* \\
\cline { 2 - 8 } & & ES & 1.765 & 24.191 & 0.000 & 5.843 & Signifikan* \\
\cline { 2 - 8 } & RS & RL & 1.716 & 28.445 & 0.000 & 5.561 & Signifikan* \\
\cline { 2 - 8 } & & ES & 2.414 & 60.634 & 0.000 & 11.178 & Signifikan* \\
\cline { 2 - 8 } & RL & ES & 0.698 & 4.948 & 0.026 & 2.010 & Signifikan* \\
\hline
\end{tabular}

Catatan: *p $<0.05$.

$\mathrm{EL}=$ enthusiastic leavers $; \mathrm{RS}=$ reluctant stayers $; \mathrm{RL}=$ reluctant leavers $; \mathrm{ES}=$ enthusiastic stayers.

Tabel 1 menunjukkan hasil estimasi model dengan predictor kepuasan kerja di antara empat jenis proximal withdrawal states.

1. Karyawan perbankan dengan kepuasan kerja tinggi mempunyai peluang sebesar 0.523 kali lebih kecil untuk menjadi reluctant stayers dibandingkan menjadi enthusiastic leavers $(\mathrm{B}=-0.649$ dan $\operatorname{Exp}(\mathrm{B})=0.523)$. Semakin tinggi tingkat kepuasan kerja karyawan perbankan, maka semakin berpeluang karyawan perbankan menjadi enthusiastic leavers dibandingkan menjadi reluctant stayers.

2. Karyawan perbankan dengan kepuasan kerja tinggi mempunyai peluang lebih besar untuk menjadi reluctant leavers dibandingkan menjadi enthusiastic leavers $(\mathrm{B}=1.067$ dan $\operatorname{Exp}(B)=2.907 \approx 3$ ). Semakin tinggi kepuasan kerja karyawan perbankan, maka peluang karyawan perbankan untuk menjadi reluctant stayers sebesar tiga kali dibandingkan menjadi enthusiastic leavers.

3. Karyawan perbankan dengan kepuasan kerja tinggi mempunyai peluang lebih besar untuk menjadi enthusiastic stayers dibandingkan menjadi enthusiastic leavers $(\mathrm{B}=1.765$ dan $\operatorname{Exp}(B)=5.843 \approx 6$ ). Semakin tinggi kepuasan kerja karyawan perbankan, maka peluang karyawan perbankan untuk menjadi enthusiastic stayers sebesar enam kali 
dibandingkan menjadi enthusiastic leavers.

4. Karyawan perbankan dengan tingkat kepuasan kerja tinggi mempunyai peluang lebih besar untuk menjadi reluctant leavers dibandingkan menjadi reluctant stayers $(\mathrm{B}=1.716$ dan $\operatorname{Exp}(B)=5.561 \approx 6$ ). Semakin tinggi kepuasan kerja karyawan perbankan, maka peluang karyawan perbankan untuk menjadi reluctant leavers sebesar enam kali dibandingkan menjadi reluctant stayers.

5. Karyawan perbankan dengan kepuasan kerja tinggi mempunyai peluang lebih besar untuk menjadi enthusiastic stayers dibandingkan menjadi reluctant stayers $(\mathrm{B}=2.414$ dan $\operatorname{Exp}(B)=11.178 \approx 11)$. Semakin tinggi kepuasan kerja karyawan perbankan, maka peluang karyawan perbankan untuk menjadi enthusiastic stayers sebesar 11 kali dibandingkan menjadi reluctant stayers.

6. Karyawan perbankan dengan kepuasan kerja tinggi mempunyai peluang lebih besar untuk menjadi enthusiastic stayers dibandingkan menjadi reluctant leavers $(\mathrm{B}=0.698$ dan $\operatorname{Exp}(B)=2.010 \approx 3$ ). Semakin tinggi kepuasan kerja karyawan perbankan, maka peluang karyawan perbankan untuk menjadi enthusiastic stayers sebesar dua kali dibandingkan menjadi reluctant leavers.

Hasil penelitian ini menunjukkan bahwa kepuasan kerja memiliki pengaruh yang signifikan terhadap proximal withdrawal states pada karyawan di perusahaan perbankan. Semakin tinggi tingkat kepuasan kerja, maka semakin besar peluang karyawan perusahaan perbankan untuk menjadi enthusiastic stayers maupun reluctant leavers.

Kedua kelompok tersebut merupakan kelompok proximal withdrawal states dengan keinginan untuk menetap di perusahaan. Sejalan dengan hasil penelitian Li et al. (2016), kepuasan kerja memiliki pengaruh negatif yang signifikan terhadap turnover, di mana pengaruh negatif tersebut semakin kuat pada kelompok proximal withdrawal states dengan keinginan menetap di perusahaan, yaitu enthusiastic stayers dan reluctant leavers. Maertz dan Campion (2004) pun mendapati bahwa karyawan dengan preferensi keluar memiliki afeksi yang lebih negatif dibandingkan dengan karyawan tipe lainnya.

\section{KESIMPULAN DAN SARAN}

Hasil penelitian ini menunjukkan bahwa kepuasan kerja memiliki pengaruh yang signifikan terhadap proximal withdrawal states pada karyawan di perusahaan perbankan. Semakin tinggi tingkat kepuasan kerja, maka semakin besar peluang karyawan perusahaan perbankan untuk menjadi enthusiastic stayers maupun reluctant leavers.

Penelitian pada 273 karyawan perusahaan perbankan menunjukkan bahwa sebagian besar partisipan penelitian merasa puas dengan pekerjaannya secara umum. Partisipan penelitian ini paling banyak berasal dari kelompok reluctant stayers, yang berarti partisipan memiliki preferensi untuk keluar dari perusahaan namun partisipan merasa tidak memiliki kendali atas preferensinya keluar dari perusahaan. Beberapa alasan partisipan tidak merealisasikan keinginannya untuk keluar adalah belum adanya pekerjaan lain, terikat dengan ikatan dinas, terikat dengan kontrak kerja, kondisi keuangan, serta kondisi partisipan yang belum kondusif untuk keluar dari perusahaan. Beberapa alasan partisipan ingin keluar dari perusahaan adalah sedang menjalani kuliah, riba, kebutuhan untuk mengurus anak, ketidaknyamanan dengan situasi kerja, tidak cocok dengan filosofi perusahaan, sudah bosan, potensi diri tidak dimaksimalkan oleh perusahaan.

Kelompok terbanyak kedua berasal dari kelompok enthusiastic stayers, yang berarti partisipan memiliki preferensi untuk menetap di perusahaan dan partisipan merasa memiliki kendali atas 
preferensinya untuk menetap di perusahaan. Sejalan dengan hasil penelitian ini, partisipan enthusiastic stayers menetap di perusahaan dengan alasan nyaman dengan pekerjaan dan lingkungan kerja, puas dengan perusahannya, nyaman dengan rekan kerja maupun atasan.

Perusahaan perbankan perlu melakukan intervensi untuk meningkatkan kepuasan kerja karyawan, mengingat semakin tingginya kepuasan kerja karyawan perbankan maka semakin besar peluang karyawan untuk menetap di perusahaan dengan menjadi enthusiastic stayers ataupun reluctant stayers. Semakin banyaknya karyawan enthusiastic stayers di perusahaan, maka tingkat turnover dapat berkurang dan jumlah karyawan yang bekerja dengan produktif (enthusiastic stayers) semakin banyak kuantitasnya di perusahaan. Selain itu, Perusahaan perbankan perlu mengenali gambaran proximal withdrawal states pada karyawan. Dengan demikian, perusahaan dapat menentukan strategi yang tepat dalam menghadapi karyawan demi mengurangi tingkat turnover di perusahaan. Karyawan dengan jenis proximal withdrawal states perlu diintervensi dengan cara yang berbeda.

Perusahaan perbankan pun perlu mengenali karyawan reluctant stayers yang jumlahnya cukup banyak di perusahaan perbankan. Reluctant stayers adalah karyawan yang sudah tidak ingin bekerja di perusahaan namun mereka secara terpaksa menetap di perusahaan karena mereka tidak dapat keluar dari perusahaan. Reluctant stayers perlu menjadi perhatian bagi perusahaan karena reluctant stayers cenderung untuk melakukan perilaku kerja yang tidak produktif bagi perusahaan (counterproductive work behavior) dan cenderung kurang melakukan perilaku produktif (organizational citizenship behaviour; Robinson, 2014). Perusahaan yang mampu mengenali karyawan jenis reluctant stayers dapat menentukan strategi yang tepat dalam menangani karyawan jenis ini agar tidak memberikan dampak negatif bagi perusahaan.

Ucapan Terima Kasih (Acknowledgement)

Peneliti mengucapkan terima kasih kepada para karyawan perbankan yang sudah bersedia berpartisipasi dalam penelitian ini. Ucapan terima kasih juga untuk pihak -pihak yang tidak dapat disebutkan satu persatu, yang telah mendukung penelitian ini.

\section{REFERENSI}

Ajzen, I. (1991). The theory of planned behavior. Organizational Behavior and Human Decision Process, 50, 179-211.

Allen, D. G., Weeks, K. P., \& Moffitt, K. R. (2005). Turnover intentions and voluntary turnover: The moderating roles of self-monitoring, locus of control, proactive personality, and risk aversion. Journal of Applied Psychology, 90(5), 980-990. doi: 10.1037/00219010.90.5.980

Brayfield, A. H., \& Rothe, H. F. (1951). An index of job satisfaction. Journal of Applied Psychology, 35(5), 307-311. doi: 10.1037/h0055617

Curry, J. P., Wakefield, D. S., Price, J. L., \& Mueller, C. W. (1986). On the causal ordering of job satisfaction and organizational commitment. Academy of Management Journal, 29(4), 847-858.

Djaja, K., Mardanugraha, E., \& Sihombing, M. (2015, August). An assessment of the Indonesian financial services sector. Paper presented at the Tripartite Workshop to Promote Social Dialogue on Financial Services Reforms in Selected Asia and Pacific Countries, Jakarta, Indonesia. Retrieved from http://www.ilo.org/wcmsp5/groups/public/---asia/---robangkok/---ilo-jakarta/documents/meetingdocument/wcms_396166.pdf 
Griffeth, R. W., Hom, P. W., \& Gaertner, S. (2000). A meta-analysis of antecedents and correlates of employee turnover: Update, moderator tests, and research implications for the next millennium. Journal of Management. 26(3), 463-488. doi: $10.1177 / 014920630002600305$

Hom, P. W., Mitchell, T. R., Lee, T. W., \& Griffeth, R. W. (2012). Reviewing employee turnover: Focusing on proximal withdrawal states and an expanded criterion. Psychological Bulletin, 138(5), 831-858. doi:10.1037/a0027983

Li, J. (J.), Lee, T. W., Mitchell, T. R., Hom, P. W., \& Griffeth, R. W. (2016). The effects of proximal withdrawal states on job attitudes, job searching, intent to leave, and employee turnover. Journal of Applied Psychology, 101(10), 1436-1456. doi:10.1037/apl0000147

Luther, L., Gearhart, T., Fukui, S., Morse, G., Rollins, A. L., \& Salyers, M. P. (2017). Working overtime in community mental health: Associations with clinician burnout and perceived quality of care. Psychiatric Rehabilitation Journal, 40(2), 252-259. doi:10.1037/prj0000234

Maertz, C. P., Jr., \& Campion, M. A. (2004). Profiles in quitting: Integrating process and content turnover theory. Academy of Management Journal, 47(4), 566-582. doi:10.2307/20159602

Mai, K. M., Ellis, A. P. J., Christian, J. S., \& Porter, C. O. L. H. (2016). Examining the effects of turnover intentions on organizational citizenship behaviors and deviance behaviors: A psychological contract approach. Journal of Applied Psychology, 101(8), 1067-1081. doi:10.1037/apl0000115

Masum, A. K. M., Azad, M. A. K., Hoque, K. E., Beh, L., Wanke, P., \& Arslan, Ö. (2016). Job satisfaction and intention to quit: An empirical analysis of nurses in Turkey. PeerJ, 4:e1896, 1-23. doi:10.7717/peerj.1896

Nicholson, K. C. (2013). Turnover reconceptualized: An exploration of the proximal withdrawal states' relationship with turnover antecedents and the act itself. (Master thesis, Ohio Institute).

Retrieved from https://etd.ohiolink.edu/pg_10?0::NO:10:P10_ACCESSION_NUM:ohiou1370364634

Prahadi, Y. Y. (2015, September 21). Turnover talent tinggi, ini dia pemicunya. SWA. Retrieved from https://swa.co.id/swa/trends/management/turnover-talent-tinggi-ini-dia-pemicunyasurvei

PwC. (2014). Indonesian banking survey 2014. Retrieved from https://www.pwc.com/id/en/publications/assets/indonesian-banking-survey-2014.pdf

Ramalho Luz, C. M. D., Luiz de Paula, S., \& de Oliveira, L. M. B. (2018). Organizational commitment, job satisfaction and their possible influences on intent to turnover. Revista de Gestão, 25(1), 84-101.doi: 10.1108/REGE-12-2017-008

Robinson, S. D. (2014). Expanding turnover theory: Testing behavioral predictions of the proximal withdrawal states and destinations (PWSD) model (Doctoral dissertation, Ohio Institute). https://etd.ohiolink.edu/pg_10?0::NO:10:P10_ACCESSION_NUM:ohiou1416255341\#a bstract-files

Romualdus, S. (2016, September 9). Potret manajemen human capital 2016. Indonesiasatu.co. Retrieved from: http://indonesiasatu.co/detail/potret-manajemen-human-capital-2016

Tett, R. P., \& Meyer, J. P. (1993). Job satisfaction, organizational commitment, turnover intention, and turnover: Path analyses based on meta-analystic findings. Personnel Psychology, 46, 259-293. 